\title{
Faktor-Faktor yang Berhubungan dengan Kematian Bayi di RSUD Ende
}

\author{
Imelda Ririn Obo Mogi ${ }^{1}$, Lina Dewi Anggraeni ${ }^{1}$, Sudibyo Supardi ${ }^{2}$ \\ ${ }^{1}$ STIK Sint Carolus \\ ${ }^{2}$ Bagian Badan Penelitian dan Pengembangan Kesehatan Kemenkes RI
}

\section{ABSTRACT}

Background: Infant mortality at the age of $\leq 1$ year per 1000 live births is one of the benchmarks for assessing the extent to which the achievement of people's welfare as a result of implementing development in the health sector. This research aimed to identify the factors associated with infant mortality in Ende Hospital.

Method: Cross-sectional design was applied in this research. Data retrieval was collected by using medical records in 2017 and 2018. There were 122 mothers had infant mortality aged $\leq 1$ year enrolled in this research with a total population sampling technique. This study used Kendal Tau-b statistical test.

Results: The results showed the highest infant mortality occurred at 0-28 days as many as 77,9\%. There was a relationship between maternal education ( $p$ value=0.042), asphyxia ( $p$-value=0.014) and infant mortality in Ende Hospital. There was no relationship between maternal age ( $p$-value $=0.602)$, maternal occupation ( $p$-value $=0.842)$, pregnancy danger signs $(p$-value $=0.713)$, birth weight ( $p$-value $=0.587)$, labor $(p$-value $=0.845)$, delivery helper $(p$-value $=0.419)$, place of delivery ( $p$-value $=0.354$ ) and infant mortality in Ende Hospital. Health workers need to consider facilities for newborn care, must be able to measure the Apgar Score for asphyxia measurement, and should provide information regarding the importance of conducting ANC examinations to prevent complication during pregnancy and asphyxia.

Correspondence

ririnmogi@gmail.com

\section{Article History}

Received 18 July 2020

Revised 26 August 2020

Accepted 5 January 2021

Available Online 6 January 2021

\section{Keywords}

Infant mortality

Maternal health

Asphyxia

\section{DOI}

10.14710/jpki.16.1.7-13

\section{PENDAHULUAN}

Angka kematian bayi (AKB) adalah banyaknya kematian bayi pada usia di bawah 1 tahun per 1.000 kelahiran hidup. AKB menjadi salah satu tolak ukur untuk menilai sejauh mana ketercapaian kesejahteraan rakyat sebagai hasil dari pelaksanaan pembangunan di bidang kesehatan. Pembangunan kesehatan ini dapat tercapai dengan meningkatkan derajat kesehatan masyarakat Indonesia. Salah satu derajat kesehatan yang belum dicapai oleh pemerintah adalah banyaknya jumlah kematian bayi ${ }^{1}$.

Laporan WHO menunjukkan bahwa sebanyak 4,5 juta bayi meninggal pada tahun pertama kehidupan. Negara Afrika merupakan salah satu negara dengan penyumbang angka kematian bayi tertinggi didunia, dengan jumlah kematian bayi di negara Afrika sebesar 55 per 1.000 kelahiran hidup ${ }^{2}$.

Angka kematian bayi di Indonesia masih cukup tinggi jika dibandingkan dengan negara ASEAN lainnya, yakni 4,2 kali lebih tinggi dari Malaysia dan 1,2 kali lebih tinggi dari negara Filipina. Berdasarkan Survei Penduduk Antar Sensus (SUPAS) pada tahun 2015 diperoleh hasil bahwa AKB sebesar 22,23 per 1.000 kelahiran hidup, yang artinya sudah mencapai target MDGs 2015 sebesar 23 per
1.000 kelahiran hidup, tetapi belum mencapai target SDG's yaitu 12 per 1000 kelahiran hidup 3 .

Dinas Kesehatan Provinsi Nusa Tenggara Timur (NTT) menjelaskan bahwa Angka Kematian Bayi di Provinsi NTT pada tahun 2012 sebesar 45 per 1.000 kelahiran hidup. Angka ini mengalami peningkatan jika dibandingkan dengan AKB tahun 2010 sebesar 39 per 1.000 kelahiran hidup ${ }^{4}$. Angka kematian bayi di Kabupaten Ende pada tahun 2015 sebesar 15,24 per 1.000 kelahiran hidup, sedangkan pada tahun 2016 AKB meningkat lagi menjadi 17,13 per 1.000 kelahiran hidup. Data ini berdasarkan hasil laporan dari RSUD Ende bahwa sebagian besar kematian bayi disebabkan oleh Berat Bayi Lahir Rendah (BBLR) dan asfiksia ${ }^{5}$.

Berdasarkan data yang didapat dari RSUD Ende, disebutkan bahwa jumlah angka kematian bayi pada tahun 2017 sebesar 43,9 kelahiran hidup. Pada bulan Januari sampai Juli tahun 2018 tercatat jumlah kematian bayi sebesar 44,8 per 1000 kelahiran hidup. Menurut data dari RSUD Ende, ditemukan banyak permasalahan yang menyebabkan kematian bayi, tetapi ada beberapa penyebab yang paling sering terjadi yaitu berat bayi lahir rendah (BBLR), berat bayi lahir amat sangat rendah (BBLASR) 
asfiksia berat, dan sepsis. Penelitian ini bertujuan untuk mengidentifikasi faktor-faktor yang berhubungan dengan kematian bayi di RSUD Ende Provinsi NTT.

\section{METODE}

Penelitian ini dilakukan di RSUD Ende pada bulan Januari 2019. Jenis penelitian yang digunakan adalah kuantitatif dengan desain penelitian cross sectional. Sampel pada penelitian ini adalah 122 ibu yang memiliki bayi meninggal usia $\leq 1$ tahun. Pengambilan sampel menggunakan rekam medis tahun 2017 dan 2018 dengan teknik total populasi. Variabel terikat dalam penelitian ini adalah kematian bayi, sedangkan variabel bebas meliputi karakteristik ibu (usia ibu, pendidikan ibu, pekerjaan ibu, tanda bahaya kehamilan) dan faktor persalinan ( $p$ valueroses persalinan, penolong persalinan, tempat persalinan, berat bayi lahir, penyakit bayi). Data dikumpulkan dengan wawancara menggunakan kuesioner terstruktur dan dianalisis secara bivariat dengan menggunakan uji kendal tau-b.

\section{HASIL DAN PEMBAHASAN}

Tabel 1. Distribusi frekuensi karakteristik ibu yang mengalami kematian bayi di RSUD Ende tahun 2017 . 2018

\begin{tabular}{lrr}
\hline \multicolumn{1}{c}{ Karakteristik Ibu } & n & \% \\
\hline Usia Ibu & & \\
$\quad$ Usia 20 thn -35 thn & 40 & 67,2 \\
Usia <20 thn dan >35 thn & & 32,8 \\
\hline Pendidikan Ibu & 71 & 58,2 \\
$\quad$ Pendidikan dasar & 54 & 41,8 \\
$\quad$ Pendidikan lanjutan & & \\
\hline Pekerjaan Ibu & 21 & 17,2 \\
$\quad$ Bekerja & 101 & 82,8 \\
$\quad$ Tidak Bekerja & & \\
\hline Tanda Bahaya Kehamilan & 16 & 13,1 \\
$\quad$ Ada & 106 & 86,9 \\
Tidak Ada &
\end{tabular}

Berdasarkan Tabel 1, dapat diketahui bahwa dari 122 responden, sebagian besar melahirkan pada usia aman $(67,2 \%)$. Sebanyak $32,8 \%$ responden berada pada usia berisiko tinggi untuk hamil, yaitu kurang dari 20 tahun dan di atas 35 tahun. Risiko ini berbahaya bagi ibu maupun janin yang dikandungnya. Sebanyak $58,2 \%$ responden mempunyai berpendidikan dasar. Pendidikan berhubungan dengan perilaku sehat, pencarian informasi kesehatan dan pengambilan keputusan yang sehat. Sebagian besar responden adalah wanita tidak bekerja $(82,8 \%)$ dan tidak mengalami tanda bahaya selama kehamilan (86,9\%), sehingga seharusnya mampu lebih optimal memperhatikan kondisi kehamilannya.

Tabel 2 menunjukkan bahwa dari 122 responden, terdapat $68,9 \%$ yang melakukan persalinan secara normal, 93,4\% yang melakukan persalinan ditolong oleh tenaga kesehatan, dan $70,5 \%$ yang melakukan persalinan di rumah sakit. Hal ini berarti terdapat dua kemungkinan, yaitu responden sudah sadar akan praktik persalinan sehat dilihat dari keputusan pemilihan layanan persalinannya, atau karena terjadinya gangguan kehamilan sehingga perlu ditangani oleh tenaga kesehatan di rumah sakit. Meskipun demikian, diperoleh hasil bahwa $74,6 \%$ bayi yang dilahirkan memiliki berat lahir tidak normal, serta 58,2\% yang memiliki penyakit asfiksia, sehingga dapat disimpulkan bahwa terjadi gangguan selama kehamilan.

Tabel 2. Distribusi frekuensi faktor persalinan pada kematian bayi di RSUD Ende tahun 2017-2018

\begin{tabular}{lrr}
\hline \multicolumn{1}{c}{ Faktor Persalinan } & n & \% \\
\hline Proses Persalinan & & \\
Normal & 84 & 68,9 \\
Tidak Normal & 38 & 31,1 \\
\hline Penolong Persalinan & & \\
Tenaga kesehatan & 144 & 93,4 \\
Bukan tenaga kesehatan & 8 & 6,6 \\
\hline Tempat Persalinan & & \\
RSUD & 86 & 70,5 \\
Tempat praktik bidan & 5 & 4,1 \\
Puskesmas & 22 & 18,0 \\
Rumah Ibu & 9 & 7,4 \\
\hline Berat Bayi Lahir & & \\
Normal & 31 & 25,4 \\
Tidak Normal & 91 & 74,6 \\
\hline Penyakit Bayi & & \\
Asfiksia & 71 & 58,2 \\
Pneumonia & 6 & 4,9 \\
Sepsis & 29 & 23,8 \\
RDS & 13 & 10,7 \\
Kelainan Kongenital & 3 & \\
\hline
\end{tabular}

Tabel 3. Distribusi frekuensi usia kematian bayi di RSUD Ende tahun 2017-2018

\begin{tabular}{lrr}
\hline Usia Bayi & n & \% \\
\hline 0-28 hari (neonatus) & 95 & 77,9 \\
29 hari - 12 bulan & 27 & 22,1 \\
\hline
\end{tabular}

Berdasarkan tabel 3 dapat diketahui bahwa sebagian besar bayi yang meninggal berada pada usia neonatus. Bayi neonatus dengan BBLR lebih berisiko mengalami kematian daripada yang tidak. Dari 122 responden, terdapat 77,9\% 
bayi yang meninggal pada usia $0-28$ hari, 22,1\% meninggal di usia 29 hari-12 bulan. Pendidikan ibu (p-value=0,042) dan asfiksia bayi (p-value=0,014) berhubungan dengan kematian bayi. Usia ibu (p-value=0,602), pekerjaan ibu (pvalue $=0,842)$, tanda bahaya kehamilan ( $\mathrm{p}$-value $=0,713)$, berat bayi lahir (p-value $=0,587)$, sepsis bayi ( $\mathrm{p}$ value $=0,100)$, proses persalinan ( $\mathrm{p}$-value $=0,845)$, penolong persalinan ( $\mathrm{p}$-value $=0,419)$ dan tempat persalinan ( $\mathrm{p}$ value $=0,354$ ) tidak berhubungan dengan kematian bayi.

\section{Hubungan usia ibu dengan kematian bayi}

Berdasarkan Tabel 4 diketahui bahwa mayoritas $(79,3 \%)$ usia ibu yang memiliki bayi usia 0-28 hari termasuk dalam kategori usia aman melahirkan, yaitu 20-35 tahun. Hasil uji Kendall's tau-b didapatkan p-value sebesar
0,602, sehingga dapat disimpulkan bahwa tidak ada hubungan antara usia ibu dengan kematian bayi.

Hasil ini sejalan dengan penelitian terdahulu yang menunjukkan tidak terdapat hubungan usia ibu dengan kematian bayi $(\mathrm{p} \text {-value }=0,407)^{6}$. Hasil penelitian ini sejalan dengan penelitian Budiati yang mengatakan bahwa usia ibu tidak berhubungan dengan kematian neonatal (pvalue $=0,063)^{7}$ dan berbeda dengan penelitian Salis (pvalue $=0,002)^{8}$.

Tidak ada hubungan antara usia ibu dengan kematian bayi dalam penelitian ini. Hal ini disebabkan karena mayoritas ibu memilki usia yang aman melahirkan. Ibu yang berusia 20 tahun sampai 35 tahun sedang memiliki rahim yang matang dan berkembang baik sehingga memiliki risiko lebih kecil untuk terjadi kematian bayi dibandingkan dengan usia ibu $<20$ tahun dan $>35$ tahun.

Tabel 4. Faktor yang berhubungan dengan kematian bayi di RSUD Ende tahun 2017-2018

\begin{tabular}{|c|c|c|c|c|c|c|c|}
\hline \multirow{3}{*}{ Faktor-faktor } & \multicolumn{4}{|c|}{ Kematian bayi } & \multirow{2}{*}{\multicolumn{2}{|c|}{ Total }} & \multirow{3}{*}{ P-value } \\
\hline & \multicolumn{2}{|c|}{ 0-28 hari } & \multicolumn{2}{|c|}{29 hari-12 bulan } & & & \\
\hline & $\mathbf{n}$ & $\%$ & $\mathbf{n}$ & $\%$ & $\mathbf{n}$ & $\%$ & \\
\hline \multicolumn{8}{|l|}{ Usia Ibu } \\
\hline Usia aman & 65 & 79,3 & 17 & 20,7 & 82 & 100 & 0,602 \\
\hline Usia berisiko & 30 & 75,0 & 10 & 25,0 & 40 & 100 & \\
\hline \multicolumn{8}{|l|}{ Pendidikan Ibu } \\
\hline Pendidikan dasar & 60 & 84,5 & 11 & 15,5 & 71 & 100 & 0,042 \\
\hline Pendidikan lanjutan & 35 & 68,6 & 16 & 31,4 & 51 & 100 & \\
\hline \multicolumn{8}{|l|}{ Pekerjaan Ibu } \\
\hline Bekerja & 16 & 76,2 & 5 & 23,8 & 21 & 100 & 0,842 \\
\hline Tidak Bekerja & 79 & 78,2 & 22 & 21,8 & 101 & 100 & \\
\hline \multicolumn{8}{|l|}{ Tanda Bahaya Kehamilan } \\
\hline Ada & 13 & 81,3 & 3 & 18,8 & 16 & 100 & 0,713 \\
\hline Tidak ada & 82 & 77,4 & 24 & 22,6 & 106 & 100 & \\
\hline \multicolumn{8}{|l|}{ Berat Bayi Lahir } \\
\hline Normal & 23 & 74,2 & 8 & 25,8 & 31 & 100 & 0,587 \\
\hline Tidak normal & 72 & 79,1 & 19 & 20,9 & 91 & 100 & \\
\hline \multicolumn{8}{|l|}{ Asfiksia } \\
\hline Ada & 61 & 85,9 & 10 & 14,1 & 71 & 100 & 0,014 \\
\hline Tidak ada & 34 & 66,7 & 17 & 33,7 & 51 & 100 & \\
\hline \multicolumn{8}{|l|}{ Sepsis } \\
\hline Ada & 19 & 65,5 & 10 & 34,5 & 29 & 100 & 0,100 \\
\hline Tidak ada & 76 & 81,7 & 17 & 18,3 & 93 & 100 & \\
\hline \multicolumn{8}{|l|}{ Proses persalinan } \\
\hline Normal & 65 & 77,4 & 19 & 22,6 & 84 & 100 & 0,845 \\
\hline Tidak normal & 30 & 78,9 & 8 & 21,2 & 38 & 100 & \\
\hline \multicolumn{8}{|l|}{ Penolong persalinan } \\
\hline Tenaga kesehatan & 88 & 77,2 & 26 & 22,8 & 114 & 100 & 0,419 \\
\hline Bukan tenaga kesehatan & 7 & 87,5 & 1 & 12,5 & 8 & 100 & \\
\hline \multicolumn{8}{|l|}{ Tempat persalinan } \\
\hline RSUD & 69 & 80,2 & 17 & 19,8 & 86 & 100 & 0,354 \\
\hline Bukan RSUD & 26 & 72,2 & 10 & 27,8 & 36 & 100 & \\
\hline
\end{tabular}


Penelitian ini melaporkan tidak terdapat hubungan antara usia ibu dengan kematian bayi, namun perlu diwaspadai apabila usia ibu kurang dari 20 tahun yang merupakan usia rentan karena masih rahim berada pada tahap reproduksi awal. Pada usia ini, organ reproduksi belum berkembang secara sempurna sehingga dapat berisiko terjadi gangguan pertumbuhan janin saat dikandungan. Pada usia lebih dari 35 tahun, ibu sudah mulai mengalami berbagai macam penyakit atau komplikasi yang dapat menurunkan kemampuan ibu dalam melakukan persalinan secara normal.

\section{Hubungan pendidikan ibu dengan kematian bayi}

Mayoritas ibu $(84,5 \%)$ yang memiliki bayi usia 0 28 hari berpendidikan dasar. Dari hasil uji Kendall's tau-b didapatkan p-value sebesar 0,042 sehingga dapat disimpulkan bahwa ada hubungan pendidikan ibu dengan kematian bayi di RSUD Ende.

Hal ini sejalan dengan penelitian yang dilakukan pada tahun 2011 yang menunjukkan ada hubungan pendidikan ibu dengan kematian bayi ( $\mathrm{p}$-value $=0,006)^{9}$. Penelitian terdahulu menyatakan bahwa ada hubungan pendidikan ibu dengan kematian bayi (p-value $=0,000)^{10}$. Hal ini berbeda dengan penelitian yang dilakukan oleh Kusumawardani dan Sri Handayani yang menunjukkan tidak ada hubungan pendidikan ibu dengan kematian bayi $(\mathrm{p} \text {-value }=0,557)^{11}$.

Ada hubungan pendidikan ibu dengan kematian bayi. Hal ini dikarenakan banyak ibu yang putus sekolah di usia muda dan juga tinggal di daerah yang ekonomi maupun teknologinya yang masih cukup rendah, sehingga kurang mendapatkan dan kurang menggali informasi terkait pentingnya kesehatan. Banyak ibu berpendidikan rendah yang memiliki bayi meninggal disebabkan karena kurangnya pengetahuan ibu dalam mencari atau mendapatkan informasi terkait pemeriksaan kehamilan atau antenatal care (ANC). Hal ini sejalan dengan penelitian yang dilakukan oleh Aisyan bahwa pendidikan ibu yang rendah berpengaruh terhadap kematian bayi. Hal ini dikarenakan faktor tingkat pendidikan yang rendah akan menyebabkan rendahnya pengetahuan ibu saat hamil sehingga ibu tidak mengetahui pentingnya pemeriksaan kehamilan ${ }^{12}$. Oleh sebab itu, pendidikan sangat dibutuhkan untuk meningkatkan intelektual seseorang yang dapat berpengaruh pada wawasan, cara berpikir, baik dalam mengambil keputusan maupun kebijakan.

\section{Hubungan pekerjaan ibu dengan kematian bayi}

Sebanyak 78,2\% ibu yang memiliki bayi usia 0-28 hari tidak memiliki pekerjaan, sedangkan ibu yang memiliki bayi usia 0-28 hari yang bekerja sebesar 76,2\%. Dari hasil uji Kendall's tau-b didapatkan p-value sebesar 0,842 sehingga dapat disimpulkan bahwa tidak ada hubungan pekerjaan ibu dengan kematian bayi di RSUD Ende.

Hal ini sejalan dengan penelitian yang dilakukan oleh Ainindya dan Solikhin yang mengatakan bahwa tidak ada hubungan pekerjaan ibu dengan kematian bayi (pvalue $=0,684)^{13}$. Penelitian yang juga dilakukan oleh Salis menunjukan tidak ada hubungan pekerjaan ibu dengan kematian bayi $p=0,248 .{ }^{8} \mathrm{Hal}$ ini berbeda dengan penelitian yang dilakukan oleh Budiati yang menunjukkan ada hubungan pekerjaan ibu dengan kematian bayi ( $\mathrm{p}$ value $=$ $0,007)^{7}$.

Pekerjaan tidak berhubungan dengan terjadinya kematian bayi. Hal ini dikarenakan ibu yang tidak bekerja memiliki waktu yang lebih banyak untuk melakukan pemeriksaan dan merawat kehamilan dibandingkan dengan ibu yang bekerja. Hal ini sejalan dengan penelitian yang dilakukan oleh Dinas Kesehatan Kabupaten Ende yang menunjukkan bahwa dengan adanya status pekerjaan atau memiliki kesibukan lain selain menjadi sebagai ibu rumah tangga bisa membuat ibu hamil mengalami kelelahan. Dengan demikian, ibu memiliki minim waktu untuk melakukan pemeriksaan kehamilan ke layanan kesehatan, sehingga jika ada gangguan kehamilan, maka kondisi tersebut tidak dapat ditangani secara optimal ${ }^{5}$.

\section{Hubungan tanda bahaya kehamilan dengan kematian bayi}

Ibu yang memiliki tanda bahaya kehamilan dan memiliki bayi usia 0-28 hari sebesar $81,3 \%$, sedangkan ibu yang tidak memiliki tanda bahaya kehamilan, dengan usia bayi 0-28 hari sebesar 77,4\%. Dari hasil uji Kendall's tau- $b$ didapatkan p-value sebesar 0,713, sehingga dapat disimpulkan bahwa tidak ada hubungan tanda bahaya kehamilan dengan kematian bayi di RSUD Ende. Hal ini sejalan dengan penelitian yang dilakukan oleh Kusumawardhani dan Sri Handayani yang mengatakan bahwa tidak ada hubungan tanda bahaya kehamilan dengan kematian bayi $(\mathrm{p} \text {-value }=0,181)^{11}$.

Hal ini berbanding terbalik dengan penelitian yang dilakukan oleh Aisyan yang menunjukkan ada hubungan tanda bahaya kehamilan dengan kematian bayi $(\mathrm{p}=0,001)^{12}$. Tanda bahaya kehamilan tidak memiliki hubungan dengan kematian bayi, hal ini dikarenakan banyak ibu yang tidak memiliki komplikasi atau tanda bahaya saat kehamilan sehingga kemungkinan untuk terjadinya kematian bayi sangat sedikit dibandingkan dengan ibu yang memiliki tanda bahaya kehamilan.

\section{Hubungan berat bayi lahir dengan kematian bayi}

Berdasarkan Tabel 4 diketahui bahwa bayi yang memiliki berat lahir tidak normal usia 0-28 hari yaitu sebesar 79,1\%. Dari hasil uji Kendall's tau $b$ didapatkan pvalue sebesar 0,587 , sehingga dapat disimpulkan bahwa 
tidak ada hubungan berat bayi lahir dengan kematian bayi di RSUD Ende.

Hal ini sejalan dengan penelitian yang dilakukan oleh Wina Rahmania yang menunjukkan tidak ada hubungan berat bayi lahir dengan kematian bayi (pvalue $=0,592)^{15}$. Hal ini berbanding terbalik dengan penelitian yang dilakukan oleh Rini dan Nunik yang menunjukkan ada hubungan berat bayi lahir dengan kematian bayi ( $\mathrm{p}$-value $=0,000)^{16}$.

Berat bayi lahir tidak memiliki hubungan dengan kematian bayi walaupun banyak bayi yang lahir dengan berat tidak normal. Hal ini dikarenakan penanganan yang baik dari tenaga kesehatan pada waktu bayi lahir, dengan cara tenaga kesehatan memberikan informasi kepada ibu untuk memberikan ASI kepada bayi setiap 2 jam sekali untuk meningkatkan imunitas dan berat badan bayi. Berat bayi yang dilahirkan dapat dipengaruhi oleh status gizi ibu baik sebelum hamil maupun saat hamil. Status gizi ibu yang kurang sebelum hamil maupun saat hamil, mempunyai risiko untuk melahirkan bayi dengan berat lahir rendah, oleh sebab itu pentingnya informasi dari tenaga kesehatan kepada ibu terkait gizi yang baik sebelum hamil maupun saat hamil.

\section{Hubungan penyakit asfiksia dan sepsis dengan kematian bayi}

Bayi yang memiliki penyakit asfiksia usia 0-28 hari yaitu sebesar 85,9\%, sedangkan yang tidak ada penyakit asfiksia pada bayi usia 0-28 hari sebesar 66,7\%. Dari hasil uji Kendall's tau-b didapatkan p-value sebesar 0,014, dapat disimpulkan ada hubungan penyakit asfiksia dengan kematian bayi di RSUD Ende. Hal ini sejalan dengan penelitian yang dilakukan oleh Suci dan Basuki didapat hasil uji Fisher;s Exact p-value=0,000, sehingga dapat disimpulkan ada hubungan penyakit asfiksia dengan kematian neonatal ${ }^{17}$.

Bayi yang memiliki penyakit sepsis usia 0-28 hari yaitu sebesar $65,5 \%$, sedangkan yang tidak ada penyakit sepsis pada bayi usia 0-28 hari sebesar $81,7 \%$. Dari hasil uji Kendall's tau-b didapatkan p-value sebesar 0,100, dapat disimpulkan bahwa tidak ada hubungan penyakit sepsis dengan kematian bayi di RSUD Ende. Hal ini sejalan dengan penelitian yang dilakukan oleh Putu Junara, didapatkan hasil uji Chi Square nilai p-value 0,22, artinya tidak ada hubungan penyakit sepsis dengan kematian bayi ${ }^{18}$. Hasil penelitian yang dilakukan oleh Alifak dkk berdasarkan hasil uji Chi Square nilai p-value 0,67, artinya tidak ada hubungan penyakit sepsis dengan kematian bayi. ${ }^{19}$

Penyakit sepsis tidak berhubungan dengan kematian bayi, karena berdasarkan observasi yang telah dilakukan peneliti selama di RSUD Ende, sebagian besar perawat melakukan tindakan secara intensif kepada bayi bayi lahir, dengan cara mencuci tangan sebelum dan sesudah melakukan tindakan pada bayi, memperhatikan lingkungan sekitar ruang perawatan bayi dan meminimalkan kunjungan dari keluarga ketika bayi baru lahir.

\section{Hubungan proses persalinan dengan kematian bayi}

Ibu yang melakukan proses persalinan normal dengan usia bayi 0-28 hari yaitu sebesar 77,4\%, sedangkan ibu yang melakukan persalinan tidak normal dengan usia bayi 0-28 hari sebesar 78,9\%. Dari hasil uji Kendall's tau- $b$ didapatkan p-value sebesar 0,845, dapat disimpulkan bahwa tidak ada hubungan proses persalinan dengan kematian bayi di RSUD Ende.

Hasil penelitian ini sejalan dengan penelitian yang dilakukan oleh Widianti dan Wijayanti yang menyatakan tidak ada hubungan proses persalinan dengan kematian bayi $(p \text {-value }=0,153)^{20}$. Hal ini berbeda dengan penelitian lain yang menyatakan ada hubungan proses persalinan dengan kematian bayi p-value $0,00^{21}$.

Proses persalinan tidak memiliki hubungan dengan kematian bayi. Hal ini dikarenakan banyak ibu yang melakukan persalinan secara normal dan tidak memiliki komplikasi atau penyakit penyerta yang dapat menghambat terjadinya proses persalinan.

\section{Hubungan penolong persalinan dengan kematian bayi}

Berdasarkan Tabel 4 diketahui bahwa ibu yang melakukan persalinan ditolong oleh tenaga kesehatan, yang memiliki bayi usia 0-28 hari yaitu sebesar 77,2\%, sedangkan ibu yang melakukan persalinan tidak ditolong oleh tenaga kesehatan, yang memiliki bayi usia 0-28 hari sebesar 87,5\%. Dari hasil uji Kendall's tau- $b$ didapatkan $p$ value sebesar 0,419, dapat disimpulkan bahwa tidak ada hubungan penolong persalinan dengan kematian bayi di RSUD Ende.

Hasil penelitian ini sejalan dengan penelitian yang dilakukan oleh Wijayanti yang menyatakan tidak ada hubungan penolong persalinan dengan kematian bayi ( $p$ value $=1,000)^{20}$. Penelitian terdahulu menyatakan bahwa tidak ada hubungan penolong persalinan dengan kematian p-value $0,65^{9}$. Penelitian yang juga dilakukan leh $^{22}$ yang menunjukkan tidak ada hubungan penolong persalinan dengan kematian bayi p-value 0,66 . Hal ini berbeda dengan penelitian yang dilakukan Isnaeni yang menunjukkan ada hubungan penolong persalinan dengan kematian bayi pvalue $0,01^{6}$.

Penolong persalinan tidak memiliki hubungan dengan kematian bayi. Hal ini dikarenakan banyak ibu yang telah melakukan persalinan ditolong oleh tenaga kesehatan seperti bidan, perawat maupun dokter spesialis kandungan dan juga semakin banyak tersedianya fasilitas kesehatan terdekat, sehingga seorang ibu yang tidak ditolong oleh tenaga kesehatan yang tidak mempunyai keahlian, memiliki 
risiko terjadinya kematian bayi yang lebih besar dibandingkan jika ditolong oleh tenaga kesehatan.

\section{Hubungan tempat persalinan dengan kematian bayi}

Ibu yang melakukan persalinan di RSUD yang memiliki bayi usia 0-28 hari yaitu sebesar 80,2\%, sedangkan ibu yang melakukan persalinan bukan di RSUD yang memiliki bayi usia 29 hari-12 bulan yaitu 77,2\%. Dari hasil uji Kendall's tau- $b$ didapatkan p-value sebesar 0,354, maka dapat disimpulkan bahwa tidak ada hubungan tempat persalinan dengan kematian bayi di RSUD Ende.

Hasil penelitian ini sejalan dengan penelitian Wijayanti yang menyatakan tidak ada hubungan tempat persalinan dengan kematian bayi $(p \text {-value }=1,000)^{20}$. Penelitian sebelumnya juga menyatakan tidak ada hubungan tempat persalinan dengan kematian neonatal pvalue $=0,451^{23}$. Hal ini berbeda dengan penelitian yang dilakukan oleh Izza dkk yang menunjukkan ada hubungan tempat persalinan dengan kematian bayi $(\mathrm{p}$-value $=$ $0,000)^{24}$.

Tempat persalinan tidak memiliki hubungan dengan kematian bayi. Penelitian di atas dilakukan pada mayoritas ibu yang bersalin di layanan kesehatan seperti RS dan puskesmas yang memiliki tenaga kesehatan dengan keahlian dan fasilitas yang cukup memadai. Dengan demikian, ibu hamil yang mengalami komplikasi saat persalinan dapat segera ditolong secara cepat sehingga meminimalkan terjadinya kematian bayi.

\section{SIMPULAN}

Sebagian besar ibu dengan bayi mati memiliki usia aman untuk melahirkan, berpendidikan dasar, tidak bekerja, tidak memiliki tanda bahaya kehamilan, berat bayi lahir tidak normal, memiliki bayi dengan asfiksia dan sepsis, melakukan persalinan secara normal, ditolong oleh tenaga kesehatan, dan melakukan persalinan ditempat pelayanan kesehatan. Faktor yang berhubungan dengan kematian bayi meliputi pendidikan ibu dan penyakit asfiksia. Usia ibu, pekerjaan ibu, tanda bahaya kehamilan, berat bayi lahir, penyakit sepsis, proses persalinan, penolong persalinan dan tempat persalinan tidak berhubungan dengan kematian bayi. Peran tenaga kesehatan sangat diperlukan untuk mencegah terjadinya asfiksia. Tenaga kesehatan dapat memberikan penyuluhan kepada ibu hamil agar melakukan pemeriksaan kehamilan sehingga tidak timbul komplikasi kehamilan yang dapat menyebabkan bayi lahir dengan asfiksia. Tenaga kesehatan harus mampu melakukan penilaian Apgar Skor untuk meminimalkan terjadinya asfiksia.

\section{KEPUSTAKAAN}

1. Badan Pusat Statistik. Sistem Informasi Rujukan Statistik. Jakarta. 2015. [Online]. Available: https://sirusa.bps.go.id/index.php?r=indikator/view\&id.
2. World Health Organitation. Kematian Bayi. 2015. http://www.who.int/gho/child_health/mortality/neonatal_ infant_text (accessed Jun. 13, 2018).

3. Kementerian Kesehatan Republik Indonesia. Kematian Bayi. Pusat Data dan Informasi. Jakarta. 2016.

4. Dinas Kesehatan Provinsi NTT. Kematian Bayi. Kupang. 2016.

5. Dinas Kesehatan Kabupaten Ende. Kematian Bayi. Ende. 2016.

6. Rofiqoch, Isnaeni. Hubungan Umur Ibu, Paritas dan Penolong Persalinan Dengan Kematian Neonatal di Wilayah Kerja Puskesmas Kabupaten Banjarnegara Tahun 2013, vol. Vol. 3, no, pp. 60-68, 2013, doi: https://doi.org/10.22146/jkr.36193.

7. Budiati, Iva. Faktor yang Berhubungan Dengan Kematian Neonatal Dini Usia 0-7 Hari. 2016. [Online]. Available: lib.unnes.ac.id/27956/1/6411411004.pdf.

8. Salis, Affan. Determinan Kematian Bayi di Wilayah Kabupaten Magelang Tahun 2017. 2017. [Online]. Available: http://journal.ummgl.ac.id.

9. Wulandari, Fitri Kurnia. Faktor-faktor yang Mempengaruhi Ketepatan Pengklasifikasian Kabupaten dan Kota Di Jawa Timur Berdasarkan Indikator Kesehatan Dengan Multivariate Adaptive Regression Spline (MARS). Diss. Universitas Negeri Malang, 2011.

10. Bustami, Anita. Faktor Risiko yang Berhubungan Dengan Kematian Perinatal di Kabupaten Lampung Utara Tahun 2014, vol. Vol 9, no, 2014, [Online]. Available: ejurnalmalahayati.ac.id.

11. Kusumawardani, Annisa dan Sri Handayani. Karakteristik Ibu dan Faktor Risiko Kejadian Kematian Bayi di Kabupaten Banjarnegara, vol. vol 13, no, 2018, doi: https://doi.org/10.14710/jpki.13.2.168-178.

12. Aisyan. Hubungan Antara Status Sosial Ekonomi Keluarga dengan Kematian Perinatal di Wilayah Kerja Puskesmas Baamang Unit II Sampit Kalimantan Tengah Januari-April 2010, 2011.

13. Ainindya dan Sodikin. Faktor Risiko Kematian Bayi Usia 0-28 Hari di RSD Dr. Soebandi Kabupaten Jember, vol. Vol 4. 2018. [Online]. Available: https://jurnal.unej.ac.id.

14. Sari, Tyagita Widya dan Syarizal Syarif. Hubungan Prematuritas Dengan Kematian Neonatal Di IndonesiaTahun 2010, vol. vol 1, no, 2016, doi: http://dx.doi.org/10.7454/epidkes.v1i1.1311.

15. Rachmania, Wina dan Octaviani. Faktor Yang Mempengaruhi Kematian Neonatal di Kabupaten Bogor Tahun 2015, vol. Vol 1, no, 2015, [Online]. Available: ejournal.uika-bogor.ac.id.

16. Rini, Dwi Setyo dan Nunik Puspitasari. Hubungan Status Kesehatan Neonatal Dengan Kematian Bayi. Vol.3, hal 73-80. 2014 [Online]. Available: 
http://journal.unair.ac.id/filerPDF/biometrikc3e9741ff1fu 11.pdf.

17. Cahyaning, Suci dan Basuki Notobroto. Analisis Hubungan Kunjungan Neonatal, Asfiksia dan BBLR dengan Kematian Neonatal. Vol 3, no, pp. 168-174, 20014.

18. Putra, Putu Junara. Insiden dan Faktor yang Berhubungan Dengan Sepsis Neonatal di RSUP Sanglah Denpasar. Vol $\quad$ 14. 2016. doi: https://dx.doi.org/10.14238/sp14.3.2012.205-10.

19. Alifah, Sumadiono, dan Wandita. Faktor Risiko Kematian Neonatal dengan Penyakit Membran Hialin. Vol 15. 2016. [Online]. Available: https://saripediatri.org/index.php/saripediatri/article/view/274.

20. Widayanti, Ari Widayanti dan Catur Wijayanti. Faktor Yang Berhubungan Dengan Kematian Bayi Di Kabupaten Boyolali., 2018, [Online]. Available: http://repository.urecol.org/index.
21. Zainuddin, Zulkarnair. Hubungan Jenis Persalinan Dengan Kejadian Asfiksia Neonatorum di RSUP Prof.Dr.R.D. Kandou Manad. Vol 1. 2013, doi: https://doi.org/10.35790/ecl.1.3.2013.3237.

22. Kurniawan dan Melaniani. Hubungan Paritas, Penolong Persalinan, dan Jarak Kehamilan dengan Angka Kematian Bayi di Jawa Timur. Vol 7. 2019. doi: http://dx.doi.org/10.20473/jbk.v7i2.2018.113-121.

23. Bisara, Lolong dan Lolong Pangaribuan. Hubungan Kunjungan K4 dengan Kematian Neonatal Dini di Indonesia (Analisis Lanjut Data Riskedas 2013), Vol 25, no, pp. 139-146, 2015, [Online]. Available: ejournal.litbang.kemkes.go.id.

24. Izza, Suraya. Hubungan Akses Pelayanan Kesehatan dengan Kematian Neonatal Dini, vol. vo 1, no 1, 2016, [Online]. Available: repository.uhamka.ac.id. 